Hydrol. Earth Syst. Sci. Discuss., 5, 2523-2542, 2008 www.hydrol-earth-syst-sci-discuss.net/5/2523/2008/ (C) Author(s) 2008. This work is distributed under the Creative Commons Attribution 3.0 License.
Hydrology and Earth System Sciences Discussions

open-access review for the journal Hydrology and Earth System Sciences

\title{
Salt intrusion in the Pungue estuary, Mozambique: effect of sand banks as a natural temporary salt intrusion barrier
}

\section{S. Graas ${ }^{1}$ and H. H. G. Savenije ${ }^{1,2}$}

${ }^{1}$ Department of Management and Institutions, UNESCO-IHE Institute for Water Education, Westvest 7, PO Box 3015, 2601 DA Delft, The Netherlands

${ }^{2}$ Water Resources Section, Faculty of Civil Engineering and Applied Geosciences, Delft University of Technology, Stevinweg 1, PO Box 5048, 2600 GA Delft, The Netherlands

Received: 1 August 2008 - Accepted: 7 August 2008 - Published: 3 September 2008

Correspondence to: S. Graas (s.graas@unesco-ihe.org)

Published by Copernicus Publications on behalf of the European Geosciences Union.

Salt intrusion in the

Pungue estuary

S. Graas and

H. H. G. Savenije

Title Page

Abstract

Introduction

Conclusions

References

Tables

Figures

14

$>$ I

4

Back

Close

Full Screen / Esc

Printer-friendly Version

Interactive Discussion 


\section{Abstract}

This paper presents a salt intrusion model for the Pungue estuary with the aim to determine the minimum discharge required to prevent the salt intrusion from reaching the water intake situated $82 \mathrm{~km}$ from the estuary mouth. The Pungue river is shared 5 between Zimbabwe and Mozambique and has a large variation in precipitation and runoff. The mean monthly discharge can be as low as $8 \mathrm{~m}^{3} / \mathrm{s}$ and as high as $893 \mathrm{~m}^{3} / \mathrm{s}$. The second largest city of Mozambique, Beira, relies on the Pungue for its water supply. In the dry season it frequently occurs that the water intake has to be ceased because the salinity of the Pungue is too high.

10 The salt intrusion model used in this paper is based on a fully analytical and predictive theory which is confronted with measurements of salt intrusion and estuary topography. The paper presents the collection of estuary characteristics and the salt water intrusion measurements that were obtained by field measurements in 1993 and 2002. Using these data the salt intrusion model has successfully been applied.

15 During salinity intrusion measurements in the dry season of 1993 it was observed that sand banks in the middle zone of the estuary prevented the salt water from intruding further upstream, resulting in lower salinity levels upstream than the theoretical salt water intrusion model predicts. This effect occurs during ebb of neap and average tides and can reduce the salt water intrusion by $10 \mathrm{~km}$.

The model indicates that in a natural situation a minimum monthly discharge of $12 \mathrm{~m}^{3} / \mathrm{s}$ is required to maintain acceptable salinity levels during high water and spring tide near the water intake. The actual water discharge upstream of the water intake has to be higher, since this minimum discharge does not take into account the water abstracted for irrigation and/or urban water supply. Current water abstractions lead to salt water intrusion near the water intake at approximately $10 \%$ of the time. The model indicates that an additional water abstraction of $5 \mathrm{~m}^{3} / \mathrm{s}$ will lead to an increase in salt water reaching the intake at $10 \%$ of the time. During neap tide the sand banks act as a temporary natural salt intrusion barrier reducing the chance of salt water reaching the
HESSD

5, 2523-2542, 2008

Salt intrusion in the

Pungue estuary

S. Graas and

H. H. G. Savenije

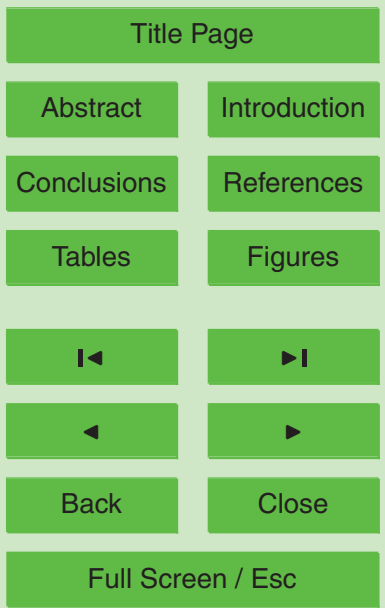

Printer-friendly Version

Interactive Discussion 
water intake.

\section{Introduction}

The Pungue river is the main source of drinking water for the cities of Beira and Dondo and of irrigation water for the Mafambisse sugar estate in Mozambique. The raw water intake for both water users is located at about $82 \mathrm{~km}$ from the estuary mouth. In dry years the intrusion of salt water reaches the intake, which causes the intake to be interrupted. This phenomenon may happen in the dry season during spring tide. As a result pumping is interrupted for several hours near high tide. This problem has greatly affected the water supply to Beira, the second largest city of Mozambique, as well as the production of the Mafambisse sugar estate (Lamoree and Nilsson, 2000).

Savenije (1986, 1989, 1993, 2005) derived an analytical relationship between the two drivers of salt intrusion (the river runoff and the tide) and the salinity distribution at high water slack (HWS), low water slack (LWS) and mean tide (TA). This relation is fully analytical and predictive and requires data on estuary shape, river discharge 15 and tidal characteristics. The method has been successfully applied to a wide range of estuaries, including the Gambia (Savenije, 1988; Risley et al., 1993; Ervine et al., 2007), the Chao Phya (Savenije, 1989), the Casamance (Savenije and Pagès, 1992), Flushing Bay (Eaton, 2007) and the Mekong (Nguyen and Savenije, 2006; Nguyen et al., 2008). With this analytical relationship alternative solutions can be investigated for the problems experienced with the water supply to the cities of Beira and Dondo and the Mafambisse sugar estate.

In this paper, the analytical method is applied to the Pungue based on field observations carried out in 1993 and 2002. As a result, the salt intrusion over the length of the estuary as a function of tidal range and river discharge is established. Subsequently

Salt intrusion in the

Pungue estuary

S. Graas and

H. H. G. Savenije

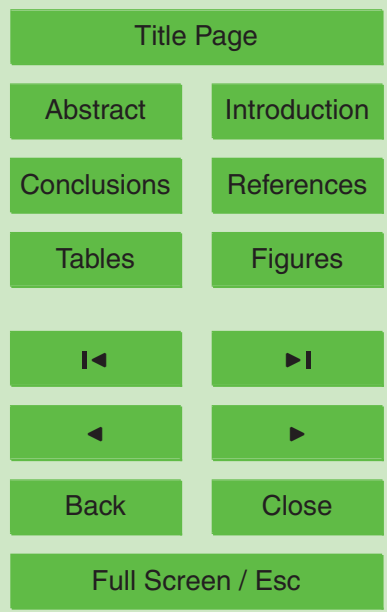

Printer-friendly Version

Interactive Discussion 


\section{Study area}

The Pungue river originates in the eastern highlands in Zimbabwe and flows eastward through Mozambique (Fig. 1). The river is $400 \mathrm{~km}$ long and drains a catchment area of $31151 \mathrm{~km}^{2}$ of which $5 \%$ is within Zimbabwean and 95\% within Mozambiquan territory.

5 The Pungue river is a perennial river with a low level of development, in terms of abstractions, diversions and regulation. Economic activities in the Pungue river basin are predominantly subsistence agriculture and livestock with some large commercial farms in the lower basin (sugar cane) and in the upper Zimbabwean part (forestry, coffee and tea). The Pungue river is the main source of water supply for the two urban centres of Beira (Mozambique) and Mutare (Zimbabwe). Currently the abstraction of water for Mutare, which is located outside the river basin and receives water through a tunnel, is restricted to a maximum of $0.7 \mathrm{~m}^{3} / \mathrm{s}$. The future growth of water demand in Mutare may entail an increased rate of abstraction from the Pungue, possibly also construction of a new water storage facility. Two main protected conservation areas are located within the Pungue Basin. The Gorongosa National Park in Mozambique covers $20 \%$ of the basin in the north-east corner, while the Nyanga National Park in Zimbabwe occupies less than $1 \%$ of the basin in the very upper parts of the basin (Sweco and Associates, 2004).

The mean annual discharge of the Pungue river, measured at Bué Maria (approx20 imately $180 \mathrm{~km}$ from the estuary mouth), is in the order of $100 \mathrm{~m}^{3} / \mathrm{s}$. The Pungue however experiences both severe floods and periods of prolonged droughts. The large seasonal variation in precipitation causes the runoff to fluctuate considerably. The average monthly discharge varies between $8 \mathrm{~m}^{3} / \mathrm{s}$ (October 1971) and $893 \mathrm{~m}^{3} / \mathrm{s}$ (March 1978).

HESSD

5, 2523-2542, 2008

Salt intrusion in the

Pungue estuary

S. Graas and

H. H. G. Savenije

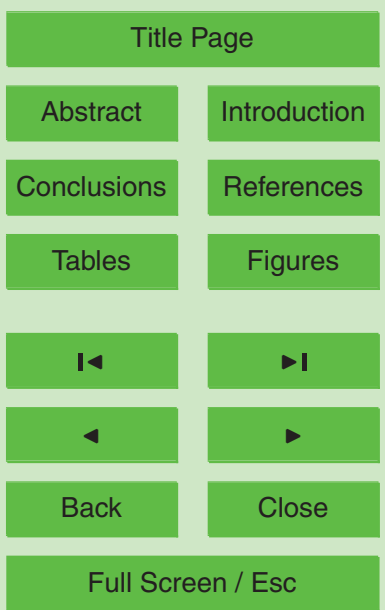

Printer-friendly Version

Interactive Discussion 


\section{Methodology}

Predictive model for steady state salt intrusion

HESSD

Savenije $(1986,1989,1993,2005)$ developed a method that predicts the salinity along the estuary axis depending on the shape of the estuary, the tidal influence and the river discharge.

The cross-sectional area and width of the estuary are described by exponential functions:

$A=A_{0} \exp \left(-\frac{x}{a}\right)$

$B=B_{0} \exp \left(-\frac{x}{b}\right)$

10 $\quad A\left(\mathrm{~L}^{2}\right)$ and $B(\mathrm{~L})$ are the cross-sectional area and width at a distance $x(\mathrm{~L})$ from the estuary mouth, $A_{0}\left(\mathrm{~L}^{2}\right)$ and $B_{0}(\mathrm{~L})$ are the cross-sectional area and width at the estuary mouth and $a(\mathrm{~L})$ and $b(\mathrm{~L})$ are the convergence lengths of the cross-sectional area and width respectively.

In many coastal plain estuaries it appears that the convergence length of the cross15 sectional area and width are equal and that the tidal average depth remains constant along the estuary (Savenije, 2005, p. 49). This is however not a necessary condition to apply the method.

$h(x)=h_{0}$

Where $h(\mathrm{~L})$ is the cross-sectional average water depth at distance $x(\mathrm{~L})$ from the estuary mouth and $h_{0}(\mathrm{~L})$ is the water depth at the estuary mouth.

The expression for the steady state salinity distribution in estuaries with an exponentially varying cross-section reads (see Savenije, 2005, p. 155):

$S-S_{f}=\left(S_{0}-S_{f}\right) *\left(1+\frac{K a Q_{f}}{D_{0} A_{0}}\left[\exp \left(\frac{x}{a}\right)-1\right]\right)^{\frac{1}{k}}$

Salt intrusion in the

Pungue estuary

S. Graas and

H. H. G. Savenije

Title Page

Abstract

Introduction

Conclusions

References

Tables

Figures

14

$\rightarrow 1$

4

Back

Close

Full Screen / Esc

Printer-friendly Version

Interactive Discussion 
Where,

$S=$ steady state salinity $\left(\mathrm{M} / \mathrm{L}^{3}\right)$

HESSD

$S_{f}=$ fresh water salinity $\left(\mathrm{M} / \mathrm{L}^{3}\right)$

$5,2523-2542,2008$

$S_{0}=$ salinity at the estuary mouth $\left(\mathrm{M} / \mathrm{L}^{3}\right)$

$K=$ Van der Burgh's coefficient, which is a hydraulic characteristic of estuaries and has a value between 0 and $1(-)$

$Q_{f}=$ river discharge $\left(\mathrm{L}^{3} / \mathrm{T}\right)$

$D_{0}=$ dispersion coefficient at the estuary mouth $\left(\mathrm{L}^{2} / \mathrm{T}\right)$

This expression can be used to describe the salinity under three key conditions where the steady state equation applies: High Water Slack (HWS), Low Water Slack (LWS) and Tidal Average condition (TA). The salt intrusion curve is derived for the TA 5 condition and this curve is shifted upstream or downstream over half the tidal excursion length, $E$ to derive, respectively, the HWS and LWS condition. Note that $K, a$ and $A_{0}$ are (constant) hydraulic characteristics of the estuary and therefore are the same for any condition during the year, whereas $D_{0}$ is time dependent, depending on both the river discharge and the tidal range.

10 Due to friction the tidal excursion, $E$ can be damped along the estuary. The tidal excursion convergence can be described by an exponential behavior:

$E=E_{0} \exp \left(-\frac{x}{e}\right)$

Where $E_{0}(\mathrm{~L})$ is the tidal excursion at the estuary mouth and $e(\mathrm{~L})$ is the convergence length of the tidal excursion.

Predictive equations for $K$ and $D_{0}$ exist, but contain uncertainties. When the relationship is calibrated against local observations, $K$ can be determined accurately and the predictive equation for $D_{0}$ becomes more certain. Hence, the model must be applied and calibrated on HWS and/or LWS observations, providing values for the parameters $K$ and $D_{0}$. The fresh water discharge, $Q_{f}$, however, is often unknown. Savenije

Salt intrusion in the

Pungue estuary

S. Graas and

H. H. G. Savenije

Title Page

Abstract

Introduction

Conclusions

References

Tables

Figures

14

$\rightarrow 1$

4

Back

Close

Full Screen / Esc

Printer-friendly Version

Interactive Discussion 
$(1986,2005)$ therefore combines the parameters $D_{0}$ and $Q_{f}$ into one single calibration variable, the mixing coefficient $\alpha_{0}$ :

$\alpha_{0}=-\frac{D_{0}}{Q_{f}}$

Once values for the parameters $K$ and $\alpha_{0}$ are known, either by calibration or by 5 using predictive equations, the salt water intrusion length can be determined. The salt intrusion length, $L$ is defined by (Savenije, 2005, p. 156):

$L=a \ln \left(-\frac{D_{0} A_{0}}{K a Q_{f}}+1\right)$

To solve this equation predictive semi-empirial relations for $D_{0}^{\mathrm{HWS}}$ and $E_{0}$ have to be used (Savenije, 2005, p. 60 and 166):

${ }_{10} D_{0}^{\mathrm{HWS}}=1400 \frac{h_{0}}{a} \sqrt{N_{R}}\left(U_{0} E_{0}\right)$

$E_{0}=\frac{v_{0} T}{\pi}$

$N_{R}=\frac{\Delta \rho}{\rho} \frac{g h Q_{f} T}{A_{0} E_{0} v_{0}^{2}}$

Where,

$E_{0}=$ Tidal excursion at the estuary mouth (L), which scales linear with the tidal range $H$

$N_{R}=$ Estuarine Richardson number (-)

$T=$ Tidal period $[T]$

$v_{0}=$ Tidal velocity amplitude at the estuary mouth $(\mathrm{L} / \mathrm{T})$

Salt intrusion in the

Pungue estuary

S. Graas and

H. H. G. Savenije

Title Page

Abstract

Introduction

Conclusions

References

Tables

Figures

14

$\rightarrow$

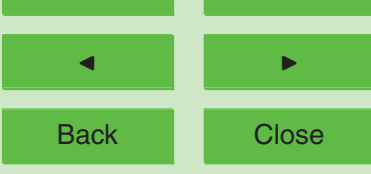

Full Screen / Esc

Printer-friendly Version

Interactive Discussion 


\section{Data}

Information on the Pungue geometry has been obtained by using satellite images and bathymetrical surveys. A satellite image of August 1999 with a spatial resolution of $530 \mathrm{~m}$ has been used to determine the width of the estuary along the $\mathrm{x}$-axis. Since in the vicinity of the water intake the width is less than $100 \mathrm{~m}$, which is not within the accuracy of the image, the width in this reach was measured during a bathymetric survey. Topographical surveys were carried out on 22 February (downstream) and 15 March (upstream) of 2002. By ways of echo-sounding and GPS the width, crosssectional area and depth were measured at several cross-sections.

It was observed during the field trips that the upstream part of the estuary has a riverine geometry without sandbanks, while the downstream part has a marine character with mud banks and the middle zone of the estuary has sandbanks with sometimes very shallow crossings. In the middle zone areas occur where during ebb at spring tide more than $75 \%$ of the cross-sections is dry. Only during high water is it possible to sail through this zone without having to drag the boat over the sand banks. The crosssectional average water depth, $h$ is along the estuary on average $3.3 \mathrm{~m}$, but locally the main channel can be more than $6 \mathrm{~m}$ deep. Figure 2 presents the single branch topography with a convergence length, $a=b$ of $16611 \mathrm{~m}$ and a constant cross-sectional average depth, $h$ of $3.3 \mathrm{~m}$. The cross-sectional area and width of the Pungue indeed vary exponentially with distance, which is in agreement with Eqs. (1) and (2).

Savenije (2005) used a more complex geometry for the Pungue estuary, which required two branches to describe the longitudinal variation of $A$ and $B$. The single branch convergence length determined in this study is however more accurate since it is based on satellite images and field measurements, as opposed to old topographical maps. The geometry of the Pungue is subject to change due to frequent flooding and unstable meandering.

Salt intrusion in the

Pungue estuary

S. Graas and

H. H. G. Savenije

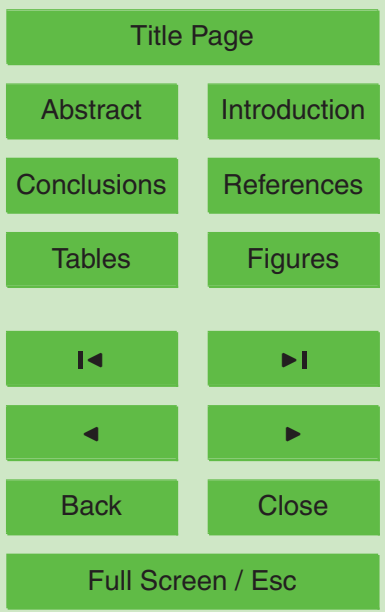

Printer-friendly Version

Interactive Discussion 
Salinity measurements were carried out during the dry season of $1993(3,12$ and 16 October) and during the rainy season of 2002 (31 January, 27 February, and 1 March). All measurements where carried out by a moving boat survey and the major5 ity during spring tide. During a moving boat survey, salinity measurements are carried out at high water and low water slack while moving upstream with the celerity of the tidal wave. At high water slack the salt intrusion is at its maximum. At each location one observes: the location, the time of observation and the salinities at different depths (Savenije, 2005, p. 153-154). The salinities were measured with a Beckman portable Salinometer.

For the Pungue estuary one needs two different boats: a fast boat during high water and a small boat (which can be easily dragged over sandbanks) during low water. Due to problems with the motor on 31 January 2002 no good salinity measurements could be taken during low water slack.

The maximum intrusion of the salinity was measured on 16 October $1993(0.2 \mathrm{~g} / \mathrm{l}$ at $89 \mathrm{~km}$ of the estuary mouth). Since the intake is located at $82 \mathrm{~km}$ from the estuary mouth the water intake must have been interrupted during this day.

Water levels

On internet the tidal predictions of the port of Beira can be retrieved for the 1993 and

2002 measurements (http://mobilegeographics.com:81/locations/483.html). Figure 3 presents the predicted water levels and indicates the periods over which the salinity measurements were carried out.

\section{River discharge}

The most downstream runoff station of the Pungue river is located at the Pungue bridge 25 (station E67), approximately $6 \mathrm{~km}$ upstream of the water intake. The discharge is
HESSD

$5,2523-2542,2008$

Salt intrusion in the

Pungue estuary

S. Graas and

H. H. G. Savenije

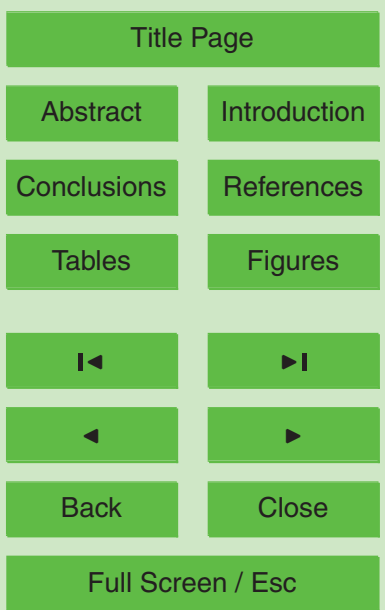

Printer-friendly Version

Interactive Discussion 
estimated by reading the water level and using a rating curve. Since the water level at the Pungue bridge is influenced by the tide the recorded runoff is considered unreliable and cannot be used. Instead the station Bué Maria (station E66) has been used to estimate the river discharge at the estuary mouth. Using only the Bué Maria station 5 means neglecting the discharge of the three tributaries Metuchira, Urema and Mudam, but this is justified since these tributaries don't contribute much, especially not in the dry season.

Based on the monthly average discharge measured at Bué Maria (October 1953September 1981) duration curves have been calculated (see Fig. 5).

\section{Salinity simulations}

Using the observed salinity distributions and the new parameters for the geometry, Eqs. (4), (5) and (6) can be used to calculate the longitudinal variation of the salinity. The calibrated results are presented in Fig. 4.

The performance of the salt intrusion model for the Pungue estuary is satisfactory. 15 Especially the measurements of 16 October 1993 (Fig. 4c) and 27 February 2002 (Fig. 4e), which are a complete set of HWS and LWS, give a good result. Most measurements show some fluctuations around the theoretical curve. The fluctuations may be caused by unequal distribution of the salinity over the cross-section or by the occurrence of fresh water pockets as a result of tidal trapping, resulting in under- or overestimation of the salinity.

During the measurements of 3 October 1993 (Fig. 4a) and 12 October 1993 (Fig. 4b) the salt intrusion is overestimated by the model in the most upstream part of the estuary. During these measurements it was observed by Zanting et al. (1994) that at $50 \mathrm{~km}$ from the estuary mouth a sand bank blocked the river completely for some time. This sand bank blocked or restrained the intrusion of saline water during neap and average tide, only allowing it to pass at high water during spring tide. In between spring tides it resulted in an accumulation of fresh water coming from upstream. Combining these
HESSD

5, 2523-2542, 2008

Salt intrusion in the

Pungue estuary

S. Graas and

H. H. G. Savenije

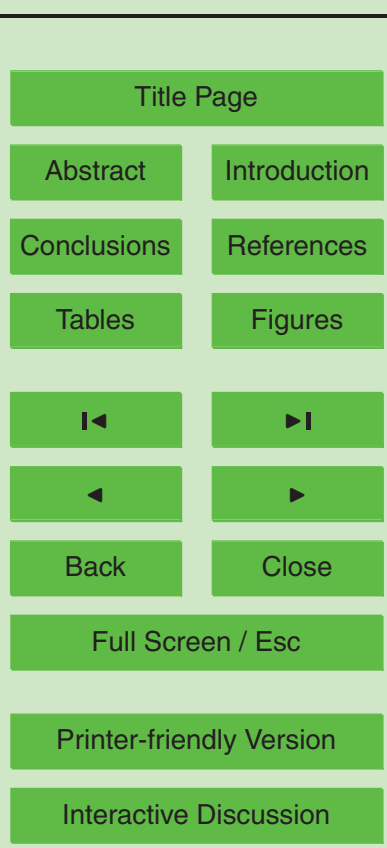


two effects it can be understood that the salt water intrudes less far than the model predicts. By moving the calculated salinity curve in the upstream part over a distance of 8-10 km this effect can be accounted for (see dotted line in Fig. 4a and 4b).

The reduction in salt water intrusion has not been measured during the measure5 ments of 16 October 1993 nor during any of the 2002 measurements. During these measurements the high water level at Beira was well above the $6.5 \mathrm{~m}$, which is apparently enough to pass the sand banks and not reduce the salt water intrusion. Of course the mixing is not instantaneous, but high water levels were already above the $6.5 \mathrm{~m}$ for 2 days before 16 October 1993 when the observations were made (see Fig. 3a). In

102002 the measurements were carried out during the wet season, resulting in higher water levels in the estuary and thus no hindrance of sand banks.

The Van der Burgh's coefficent, $K$, for the Pungue estuary here has been calibrated at 0.1. Savenije (2005) came to a Van der Burgh's coefficent of 0.3 but assumed a two-branched estuary and worked with a different convergence length, $a$. Based on

15 the satellite images of 1999 and the echo-sounding this doesn't appear to reflect the correct estuary shape of the Pungue. In fact the topography is simpler now.

\section{Salinity predictions}

Having calibrated Van der Burgh's coefficient, $K$ and the mixing coefficient, $\alpha_{0}$, we can determine the minimum discharge required to prevent salt water intrusion from reaching the water intake (using Eq. 7). In Fig. 5 the salt water intrusion length is presented for different monthly discharges and for a tidal range of $6.5 \mathrm{~m}$ (spring tide which occurs approximately $5 \%$ of the time). For smaller tidal range levels the salt water intrusion length will decrease by 1 or $2 \mathrm{~km}$.

Figure 5 shows that in the natural situation the monthly average discharge of the 25 Pungue river is enough to prevent the salt water from reaching the intake at $99 \%$ of the time. The minimum required monthly discharge amounts to $12 \mathrm{~m}^{3} / \mathrm{s}$. On a daily basis this minimum discharge can occur more often and particularly if current and future

HESSD

5, 2523-2542, 2008

Salt intrusion in the

Pungue estuary

S. Graas and

H. H. G. Savenije

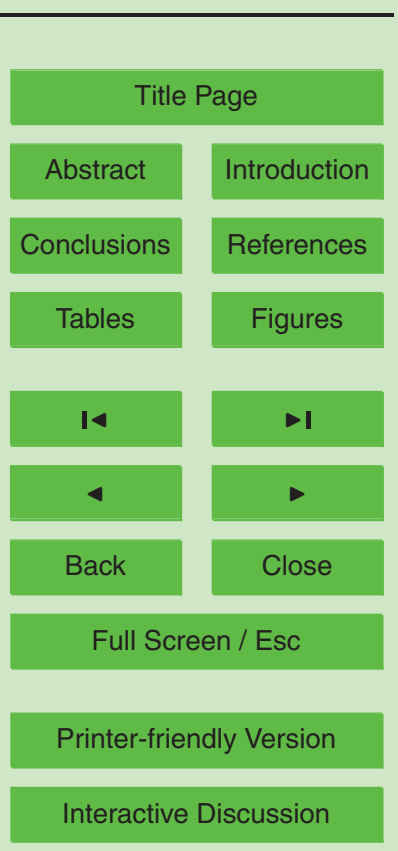


upstream water using developments in Mozambique and Zimbabwe are taken into account. Moreover, the discharge upstream of the water intake needs to be increased by $7 \mathrm{~m}^{3} / \mathrm{s}$ to account for the water abstracted by the different users (Mafambisse irrigation, urban water supply for Beira, Dondo and Mutare). These current water abstractions

5 lead to salt water problems near the intake at approximately $10 \%$ of the time. Future developments will lead to more frequent salinity problems near the water intake. Figure 5 demonstrates that an additional water abstraction of $5 \mathrm{~m}^{3} / \mathrm{s}$ will lead to an increase in the time of exceedance of approximately $10 \%$. On the other hand, the shallow zone and sand banks reduce the salt water intrusion length, during neap tide, 10 permitting a lower discharge without endangering the water intake. Whether or not the intake will have to be closed also depends on the allowed concentration of the intake water (FAO or WHO limits).

\section{Comparison with predictive model}

This salt intrusion method has been applied in 17 different estuaries all over the world, 15 particularly for HWS situations (Savenije, 2005). In Fig. 6, the measured and computed intrusion length for these 17 estuaries are plotted together with the new data for the Pungue. One can see that the predictive model predicts the salt water intrusion length for the different estuaries very well, but gives a small overestimation of the salt water intrusion length in the Pungue estuary. This overestimation can be caused by the effect of the sand banks.

\section{Conclusions}

The salt intrusion in the Pungue estuary can be adequately modelled using the theory of Savenije (2005). The model has been applied to field measurements of 1993 and 2002 giving values for the convergence length, $a$, Van der Burgh's coefficient, $K$ and

HESSD

5, 2523-2542, 2008

Salt intrusion in the

Pungue estuary

S. Graas and

H. H. G. Savenije

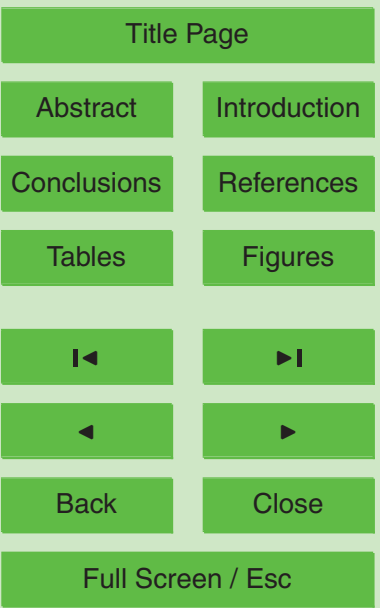

Printer-friendly Version

Interactive Discussion 
average water depth, $h$. During ebb of neap and average tide the middle zone of the estuary (approximately $50 \mathrm{~km}$ from the estuary mouth) experiences constriction by sand banks, and falls almost dry, preventing the salt water from intruding further upstream. The effect of the sand banks can reduce the salt water intrusion by $10 \mathrm{~km}$.

5 In the natural situation a minimum monthly discharge of $12 \mathrm{~m}^{3} / \mathrm{s}$ is required to prevent salt water from reaching the intake during high water of spring tide. The actual water discharge upstream of the water intake will have to be higher, since these minimum discharges do not take into account the water abstracted to supply to the irrigation and urban areas or a minimum discharge required to maintain the aquatic ecosystem. 10 Due to these current water abstractions salinity problems near the water intake occur approximately $10 \%$ of the time. An additional water abstraction of $5 \mathrm{~m}^{3} / \mathrm{s}$ will lead to an increase in the salinity intrusion and a more frequent closing of the water intake of approximately $10 \%$ of the time. During neap tide the sand banks act as a temporary natural salt intrusion barrier reducing the chance of salt water reaching the water intake.

15 Acknowledgements. The authors would like to thank the staff of ARA Centro, especially Novela, Mponda and Melembe, for their support to this research and active participation during the field measurement campaigns.

\section{References}

Eaton, T. T.: Analytical estimates of hydraulic parameters for an urbanized estuary - Flushing Bay, J. Hydrol., 347(1-2), 188-196, doi:10.1016/j.jhydrol.2007.09.018, 2007. 2525

Ervine, D. A., Bekic, D., and Glasson, L.: Vulnerability of two estuaries to flooding and salinity intrusion, Water Sci. Technol.: Water Supply, 7(2), 125-136, 2007. 2525

Lamoree, G. and Nilsson, A.: A process approach to the establishment of International River Basin Management in Southern Africa, Phys. Chem. Earth. PT B, 25(3), 315-323, doi:10.1016/S1464-1909(00)00021-6, 2000. 2525

Nguyen A. D. and Savenije, H. H. G.: Salt intrusion in multi-channel estuaries: A case study in the Mekong Delta, Vietnam, Hydrol. Earth Syst. Sc., 10, 743-754, 2006. 2525

HESSD

5, 2523-2542, 2008

Salt intrusion in the

Pungue estuary

S. Graas and

H. H. G. Savenije

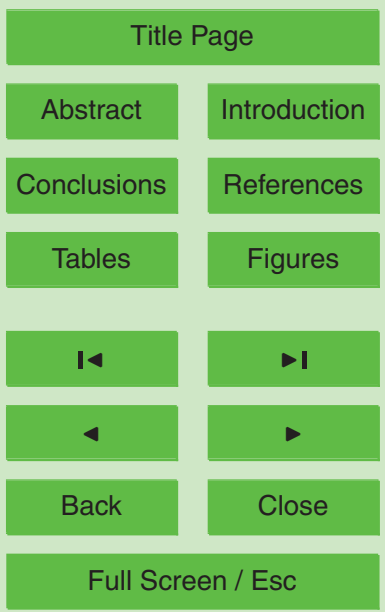

Printer-friendly Version

Interactive Discussion 
Nguyen, A. D., Savenije, H. H. G., Pham, D. N., and Tang, D. T.: Using salt intrusion measurements to determine the freshwater discharge distribution over the branches of a multi-channel estuary: The Mekong Delta case, Estuar. Coast Shelf S., 77(3), 433-445, doi:10.1016/j.ecss.2007.10.010, 2008. 2525

5 Risley, J. C., Guertin, D. P., and Fogel, M. M.: Salinity intrusion forecasting system for Gambia river estuary, J. Water Res. PI.-ASCE, 119(3), 339-352, 1993. 2525

SWECO and Associates: Development of the Pungwe River Basin Joint Integrated Water Resources Management Strategy. The Pungwe River Monograph. Main report, Sweden, 2004. 2526

10 Savenije, H. H. G.: A one-dimensional model for salinity intrusion in alluvial estuaries, J. Hydrol., 85, 87-109, doi:10.1016/0022-1694(86)90078-8, 1986. 2525, 2527, 2528

Savenije, H. H. G.: Influence of Rain and Evaporation on Salt Intrusion in Estuaries, J. Hydraul. Eng.-ASCE, 88, 1509-1524, 1988. 2525

Savenije, H. H. G.: Salt intrusion model for High Water Slack, Low Water Slack and Mean tide, on spreadsheet, J. Hydrol., 107, 9-18, doi:10.1016/0022-1694(89)90046-2, 1989. 2525, 2527

Savenije, H. H. G. and Pagès, J.: Hypersalinity, a dramatic change in the hydrology of Sahelian estuaries, J. Hydrol., 135, 157-174, doi:10.1016/0022-1694(92)90087-C, 1992. 2525

Savenije, H. H. G.: Predictive model for salt intrusion in estuaries, J. Hydrol., 148, 203-218, doi:10.1016/0022-1694(93)90260-G, 1993. 2525, 2527

Savenije, H. H. G.: Salinity and Tides in Alluvial Estuaries, Elsevier, Amsterdam, 197 pp., 2005. 2525, 2527, 2529, 2530, 2531, 2533, 2534, 2542

Zanting, H. A., Macueve, C., and Novela, B.: Salt Intrusion in the Pungue Estuary, Direcção Nacional De Águas, Maputo, Mozambique (unpublished), 1994. 2532

HESSD

$5,2523-2542,2008$

Salt intrusion in the

Pungue estuary

S. Graas and

H. H. G. Savenije

Title Page

Abstract

Introduction

Conclusions

References

Tables

Figures

14

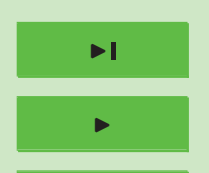

4

Back

Close

Full Screen / Esc

Printer-friendly Version

Interactive Discussion 


\section{HESSD}

5, 2523-2542, 2008

Salt intrusion in the

Pungue estuary

S. Graas and

H. H. G. Savenije

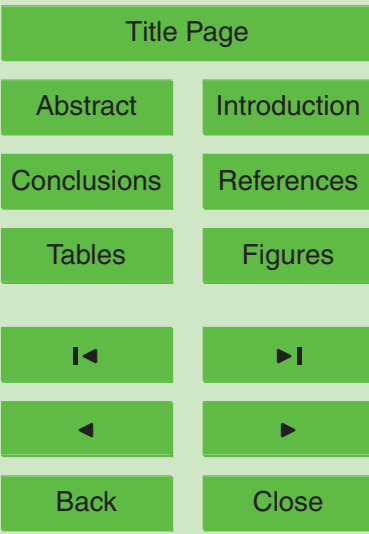

Full Screen / Esc

Printer-friendly Version

Interactive Discussion 


\section{HESSD}

5, 2523-2542, 2008

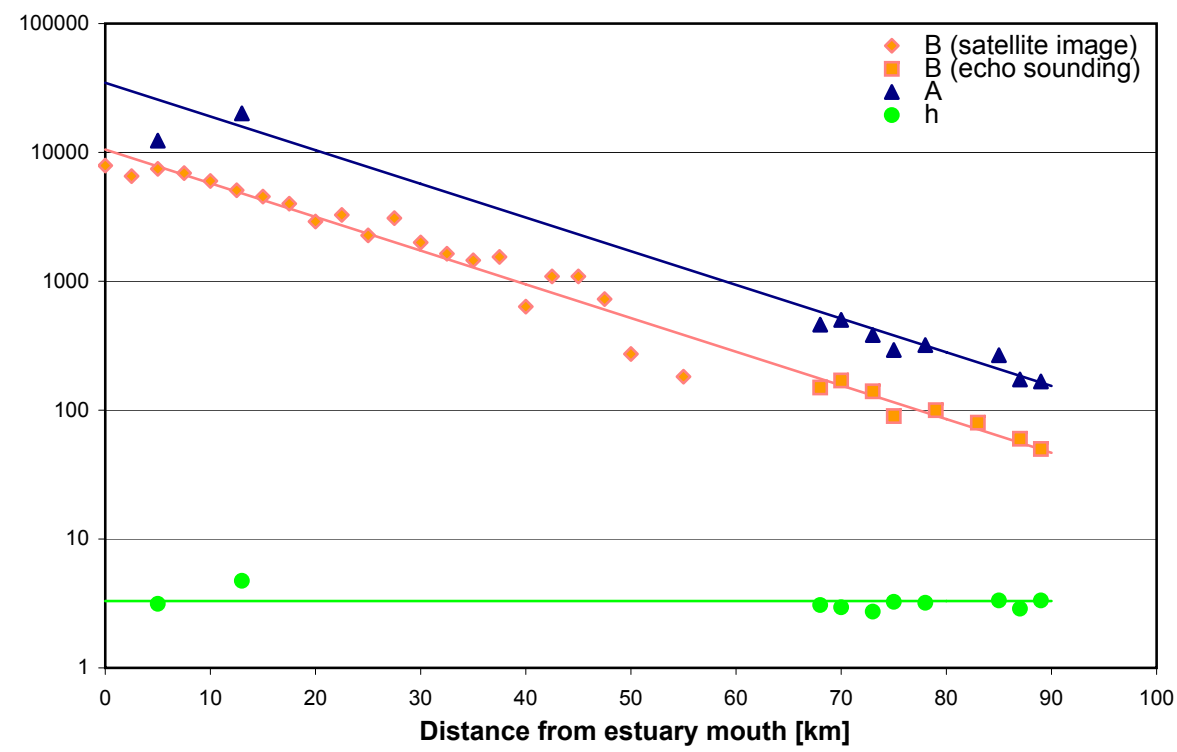

\section{Salt intrusion in the \\ Pungue estuary}

S. Graas and

H. H. G. Savenije

\section{Title Page}

Abstract

Introduction

Conclusions

References

Tables

Figures

14

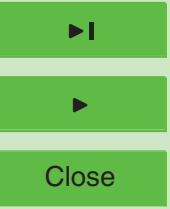

Back

Close

\section{Full Screen / Esc}

Printer-friendly Version

Interactive Discussion 
Salt intrusion in the

Pungue estuary

S. Graas and

H. H. G. Savenije

(a)

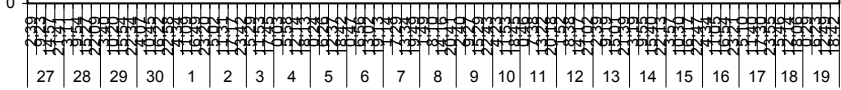

October 1993

Title Page

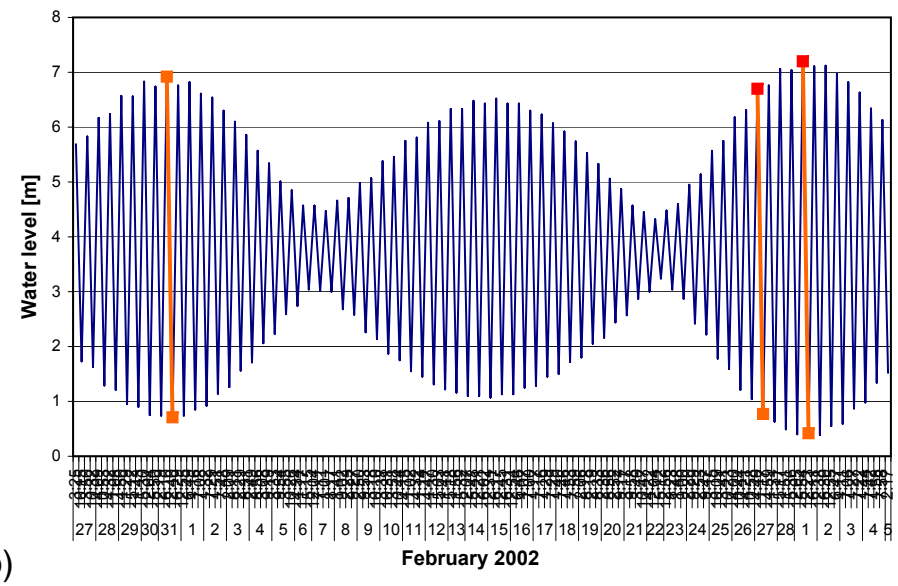

Abstract

Introduction

Conclusions References

Tables

Figures

I

4

Back

Close

Full Screen / Esc

Printer-friendly Version

Fig. 3. Predicted water levels at the port of Beira in October 1993 (a) and February 2002 (b). Bold orange line segments indicate the period of measurement.

Interactive Discussion 
(a)
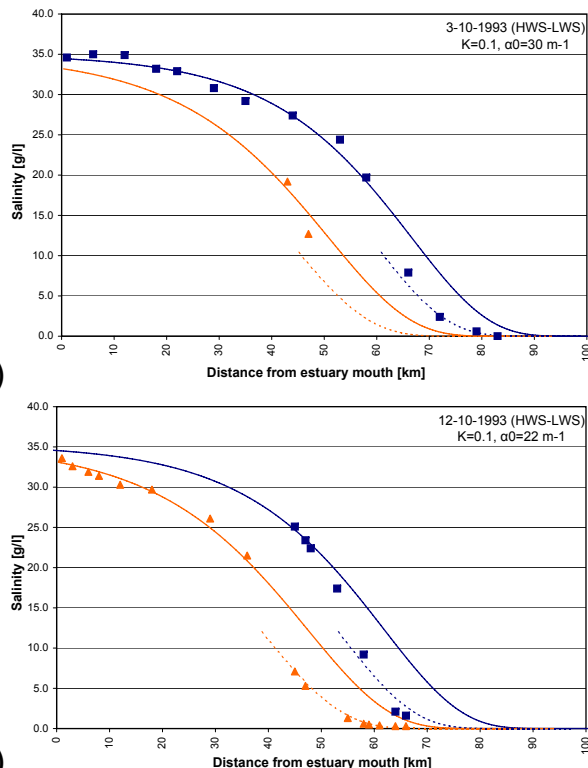

(b)

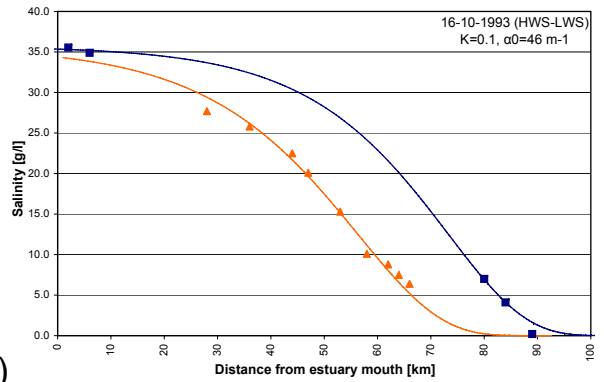

(d)
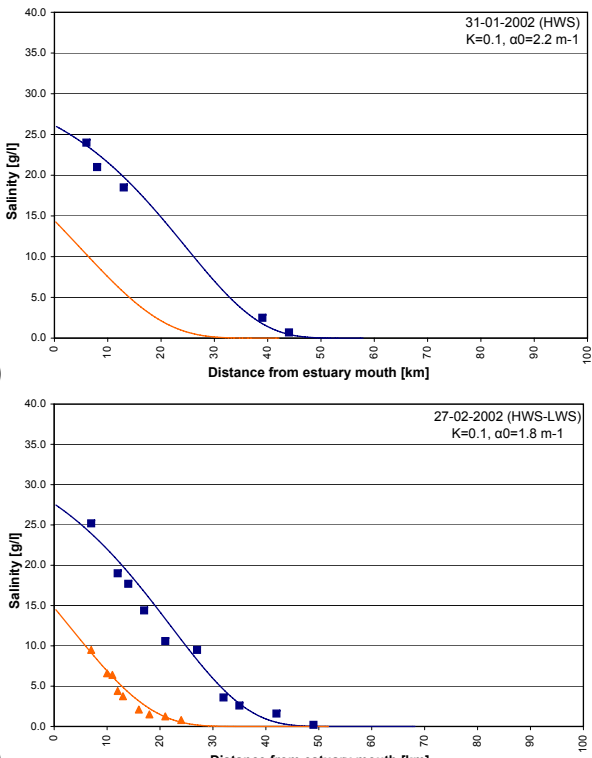

(e)

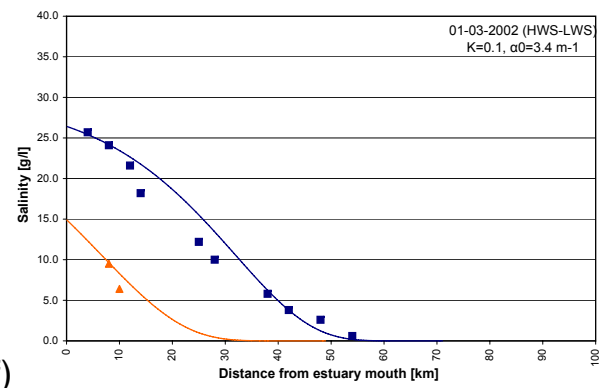

HESSD

5, 2523-2542, 2008

Salt intrusion in the

Pungue estuary

S. Graas and

H. H. G. Savenije

Title Page

Abstract

Introduction

Conclusions

References

Tables

Figures

14

$>1$

4

Back

Close

\section{Full Screen / Esc}

Printer-friendly Version

Interactive Discussion

Fig. 4. Salinity Intrusion at HWS and LWS. The measurements are indicated by symbols and the calibrated salinity curves by drawn lines. The dotted line is the shifted salinity curve due to the sandbanks. (a) on 3 October 1993 (average tide, $H_{0}=5.60 \mathrm{~m}$ ), (b) on 12 October 1993 (neap tide, $H_{0}=3.93 \mathrm{~m}$ ), (c) on 16 October 1993 (spring tide, $H_{0}=6.42 \mathrm{~m}$ ), (d) on 31 January 2002 (spring tide, $H_{0}=6.20 \mathrm{~m}$ ), (e) on 27 February 2002 (spring tide, $H_{0}=6.06 \mathrm{~m}$ ) and (f) on 1 March 2002 (spring tide, $H_{0}=6.72 \mathrm{~m}$ ). 


\section{HESSD}

5, 2523-2542, 2008

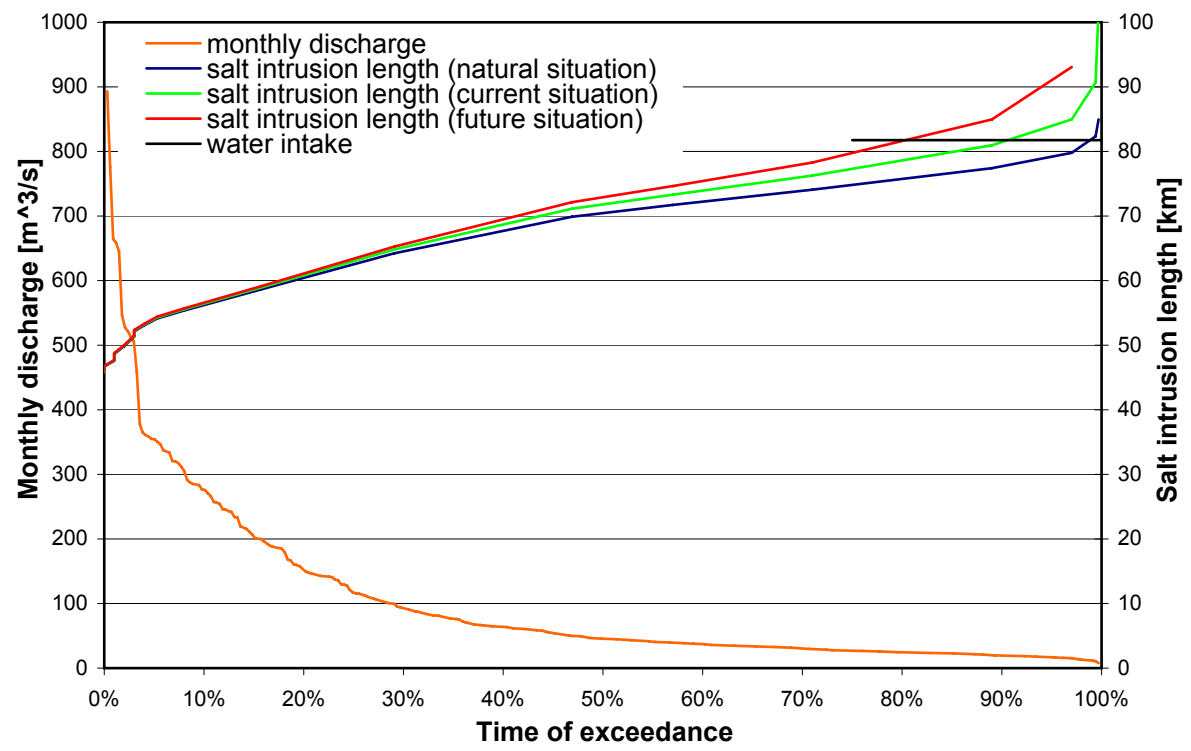

Salt intrusion in the

Pungue estuary

S. Graas and

H. H. G. Savenije

Title Page

Abstract

Introduction

Conclusions

References

Tables

Figures

14

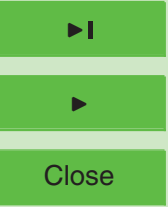

Back

Close

Full Screen / Esc

Printer-friendly Version

Interactive Discussion 


\section{HESSD}

$5,2523-2542,2008$

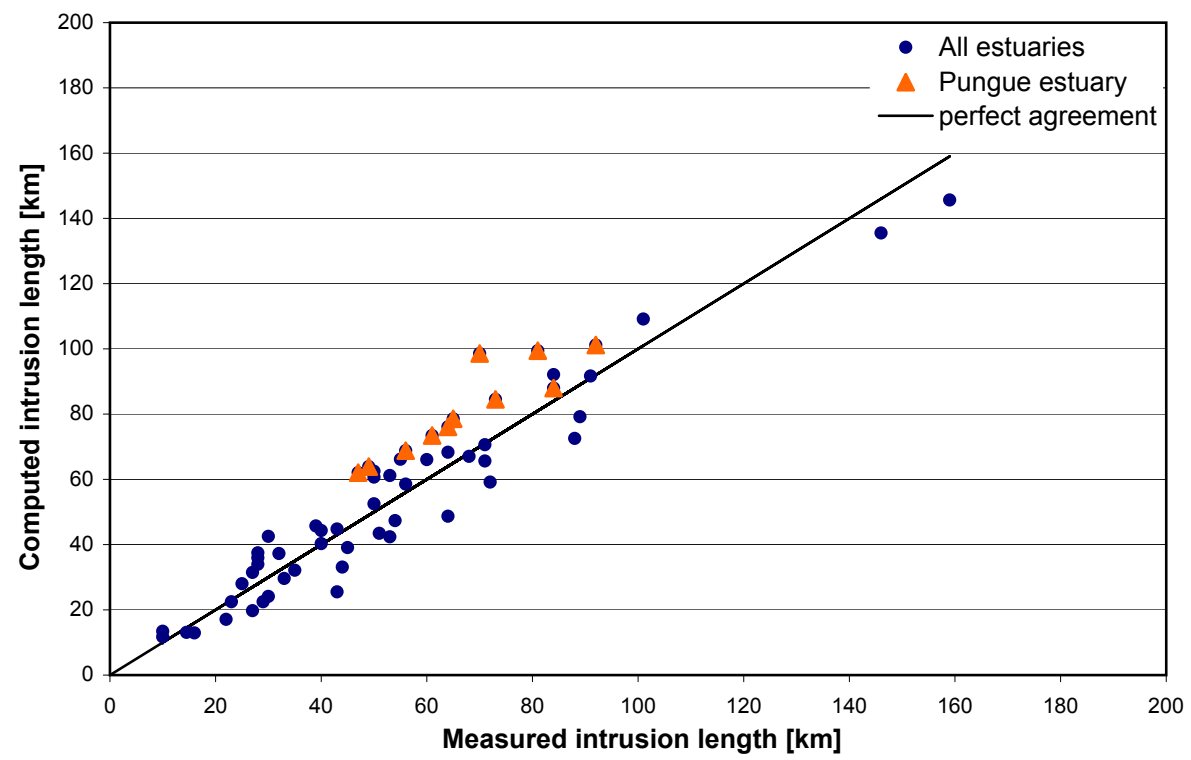

Fig. 6. Salt intrusion length at HWS according to the predictive model, applied to the Pungue and other estuaries described by Savenije (2005).

\section{Salt intrusion in the \\ Pungue estuary}

S. Graas and

H. H. G. Savenije

\section{Title Page}

\section{Abstract}

Introduction

Conclusions

References

Tables

Figures

14

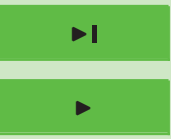

Back

Close

\section{Full Screen / Esc}

Printer-friendly Version

Interactive Discussion 